\title{
Hemorrhagic retinopathy in an infant with hemolytic-uremic syndrome
}

\author{
Retinopatia hemorrágica em lactente com síndrome hemolítico-urêmica
}

\author{
João Caetano Ávila Geraissate ${ }^{1,2}$, Rafael Eidi Yamamoto ${ }^{2}$, David Leonardo Cruvinel Isaac ${ }^{1,2}$, Marcos Pereira de Ávila ${ }^{1,2}$
}

\begin{abstract}
We describe the case of a 23-month-old female infant with a diagnosis of he molytic uremic syndrome (HUS) and hemorrhagic retinopathy. The patient had a past history of abdominal pain, bloody diarrhea, and acute renal failure. On ophthalmologic examination, indirect ophthalmoscopy revealed extensive areas of flame-shaped hemorrhage, cotton wool spots, macular edema and optic nerve head neovascularization in both eyes. Fluorescein angiography showed severe bilateral retinal ischemia and neovascularization leakage in disk. The patient, who had the visual acuity of 20/1000 in the right eye (OD) and 20/540 in the left eye (OS) at the first examination, was treated with panretinal photocoagulation (PRP) and presented at the end of the 6th month of follow-up improvement to 20/540 in OD and 20/270 in OS. There was also a regression of disc neovascularization, hemorrhages and macular edema. Despite intense retinal ischemia, there were no complications related to angiogenesis such as vitreous hemorrhage and/ or neovascular glaucoma. We describe, in this report, the association between hemorrhagic retinopathy with features of Purtscher-like disease and HUS.
\end{abstract}

Keywords: Hemolytic uremic syndrome; Retinal hemorrhage/etiology; Fluorescein angiography; Light coagulation; Infant; Case reports

\section{RESUMO}

Descrevemos o caso de um lactente do sexo feminino de 23 meses com diagnóstico de síndrome hemolítico-urêmica (SHU) eretinopatia hemorrágica. A paciente apresentou história clínica prévia de dor abdominal, diarréia sanguinolenta e insuficiência renal aguda. Ao exame oftalmológico, a oftalmoscopia indireta evidenciou, em ambos os olhos, extensas áreas de hemorragia em chama de vela, exsudatos algodonosos, edema macular e neovasos na cabeça do nervo óptico. A angiofluoresceinografia mostrou intensa isquemia retiniana bilateral e vazamento na neovascularização de disco. A paciente, a qual apresentava acuidade visual de 20/1000 no olho direito (OD) e $20 / 540$ no olho esquerdo (OE) no primeiro exame, foi tratada com panfotocoagulação retiniana e apresentou no final do 60 mês de acompanhamento a acuidade visual de 20/540 no OD e 20/270 no OE. Observou-se ainda a regressão dos neovasos, das hemorragias retininanas e do edema. Apesar da intensa isquemia retiniana não houve complicações relacionadas à angiogênese como hemorragia vítrea elou glaucoma neovascular. Descreve-se, neste relato, a associação entre retinopatia hemorrágicas com características de Purtscher-like e síndrome hemolítico-urêmica.

Descritores: Síndrome hemolítico-urêmica; Hemorragia retiniana/etiologia; Angiofluoresceinografia; Fotocoagulação; Lactente; Relato de casos

\section{INTRODUCTION}

First described in 1955 by Conrad von Gasser ${ }^{(1)}$, hemolytic uremic syndrome (HUS) is the most common cause of acute renal failure in children, with an incidence of 0.2-3.4 per 100,000 patients per year ${ }^{(2)}$. It is a complex, multisystemic disorder characterized by the triad of microangiopathic hemolytic anemia, thrombocytopenia and acute renal failure (ARF). The main differential diagnosis is thrombotic thrombocytopenic purpura (TTP) accompanied by the classic triad of HUS, fever, and neurological disorders ${ }^{(3)}$. HUS is divided into two presentation forms determined by different clinical and pathophysiological conditions. The classical or typical HUS is the most frequent, accounting for $90 \%$ of cases. Its incidence increases in summer due to a correlation with intestinal infection caused by Escherichia coli (0157: H7) and production of verotoxin ${ }^{(4)}$. The atypical form is a heterogeneous group associated with genetic predisposition, systemic inflammatory disease, pregnancy, organ transplantation, use of medications, and other infections, either viral or bacterial, outside the gastrointestinal tract ${ }^{(2,5)}$. In most cases, HUS is preceded by gastroenteritis, sudden abdominal pain, watery or bloody diarrhea, nausea, vomiting, and mild fever, with onset typically occurring within three days of exposure to the toxin. Other signs upon physical examination include pallor, oliguria, dehydration, edema, petechiae, hepatosplenomegaly, and neurological signs. To establish the diag- nosis, necessary tests should include complete blood count (CBC), stool culture, biochemistry (including renal function, bilirubin, lactate dehydrogenase and plasma electrolytes), urinalysis, and serology for detection of antilipopolysaccharide (LPS) serotypes of E. coli that produce verotoxin. The classic HUS is a self-limiting disease with high rates of full recovery mainly when early and adequate treatments of symptoms are provided ${ }^{(6)}$.

Ocular involvement in pediatric patients with HUS has rarely been reported and includes retinal, choroid and vitreous hemorrhages as well as ischemic signs such as cotton wool spots, retinal whitening and non-perfusion zones which leads to retinal neovascularization and optic atrophy ${ }^{(7)}$. Some of these characteristics are found in Purtscher-like retinopathy. Purtscher's retinopathy was first described in 1910 by Otmar Purtscher as whitish lesions with hemorrhagic retinopathy associated with low visual acuity secondary to a fall( ${ }^{(8)}$. From 1975 Inkles introduced the term Purtscher-like retinopathy to describe the same clinical feature in a case of pancreatitis with no history of previous trauma ${ }^{(8)}$. Ever since these terms are used to describe the fundus changes as peripapillary cotton wool spots, intraretinal hemorrhages and Purtscher fleckens.

In this report, we describe a rare association between classic hemolytic uremic syndrome and hemorrhagic retinopathy in a 23-month-old infant, as well as the follow-up after retinal photocoagulation.
Submitted for publication: September 30, 2013

Accepted for publication: May 1, 2014

Study conducted at Ophthalmology Department of Universidade Federal de Goiás (UFG), Goiânia, GO, Brazil.

Ophthalmology Department, Centro de Referência em Oftalmologia (CEROF), Goiânia, GO, Brazil. 2 Ophthalmology Department, Universidade Federal de Goiás (UFG), Goiânia, GO, Brazil.
Funding: No specific financial support was available for this study.

Disclosure of potential conflicts of interest: None of the authors have any potential conflicts of interest to disclose.

Corresponding author: Rafael Eidi Yamamoto. Rua 222, 467/502. Setor Leste Universitário - Goiânia, G0 74603-160 - Brazil - E-mail: dr.rafaelyamamoto@gmail.com 


\section{CASE REPORT}

MSBO, female, 23 months old, was admitted to a primary care unit in the city of Goiás with abdominal pain, bloody diarrhea and dehydration. The case progressed with worsening of renal failure and she was referred to the Department of Nephrology of Hospital das Clínicas of Universidade Federal de Goiás (UFG), where she was diagnosed with hemolytic uremic syndrome and hemodialysis was started. On day 21 of her hospitalization, ophthalmologic evaluation was requested due to decreased vision.

On ophthalmologic examination, a preferential looking test (Teller) showed visual acuity of 20/1000 in the right eye (OD) and $20 / 540$ in the left eye (OS) at $38 \mathrm{~cm}$. Direct pupillary reflexes and ocular motility were normal. Fundus examination showed bilateral retinal hemorrhages in the four retinal quadrants, cotton wool spots, macular edema and neovascularization in the optic nerve head ( $\mathrm{Fi}$ gure 1). Fluorescein angiography showed hypofluorescent areas by blocking (hemorrhages) and filling defects (retinal ischemia), mild vascular tortuosity and late hyperfluorescence due to leakage around the optic nerve neovascularization in both eyes (Figures 2 and 3).

The proposed treatment was panretinal photocoagulation (PRP) with a binocular indirect ophthalmoscope $(\mathrm{BIO})$ in both eyes using an $810 \mathrm{~nm}$ diode laser. After 6 months there was regression of neovascularization, cotton wool spots, hemorrhages and macular edema with remaining mild epiretinal fibrosis, optic disc pallor, vascular narrowing and macular retinal pigment epithelium (RPE) atrophy (Figure 4). Final visual acuity (VA) was 20/540 in OD and 20/270 in OS on Teller acuity cards at $38 \mathrm{~cm}$.

\section{DISCUSSION}

TTP and HUS, two physiologically indistinguishable entities, are the main representatives of thrombotic microangiopathy. Clinically, the presence of ARF and the absence of fever and neurological signs led to the diagnosis of HUS, which is important because the mortality of untreated TTP with plasmapheresis and plasma infusion is up to $90 \%{ }^{(3)}$

The pathophysiological process of typical HUS comprises thrombosis and non-inflammatory necrosis by Shiga-like toxin, also called verotoxin, which is produced mainly by the strain 0157:H7 of E. coli(4). This toxin has a strong affinity to the kidneys due to its receptor to globotriaosylceramide (Gb3), a glycopeptide located mainly in the endothelium of renal vessels. This phenomenon releases vasoactive substances and platelets that activate the coagulation cascade, leading to the formation of edema and microthrombosis in arteries, arterioles and glomerular capillaries, in turn causing reduction of glomerular filtration and resulting ARF, thrombocytopenia by consumption of platelets and anemia by hemolysis of microangiopathic erythrocytes ${ }^{(9)}$. Treatment of HUS is based on the control of ARF; with blood disorders and the need for dialysis occurring in 75\%-100\% of cases because there is no treatment specific to HUS ${ }^{(10)}$.

The first ocular diagnostic impression was bilateral occlusion of the central retinal vein due to extensive areas of hemorrhage and macular edema, but knowing the pathophysiology of the underlying disease and its relationship to endothelial injury of the arteries, arterioles and capillaries, the diagnosis of Purtscher-like retinopathy was suggested because it would explain the presence of capillary
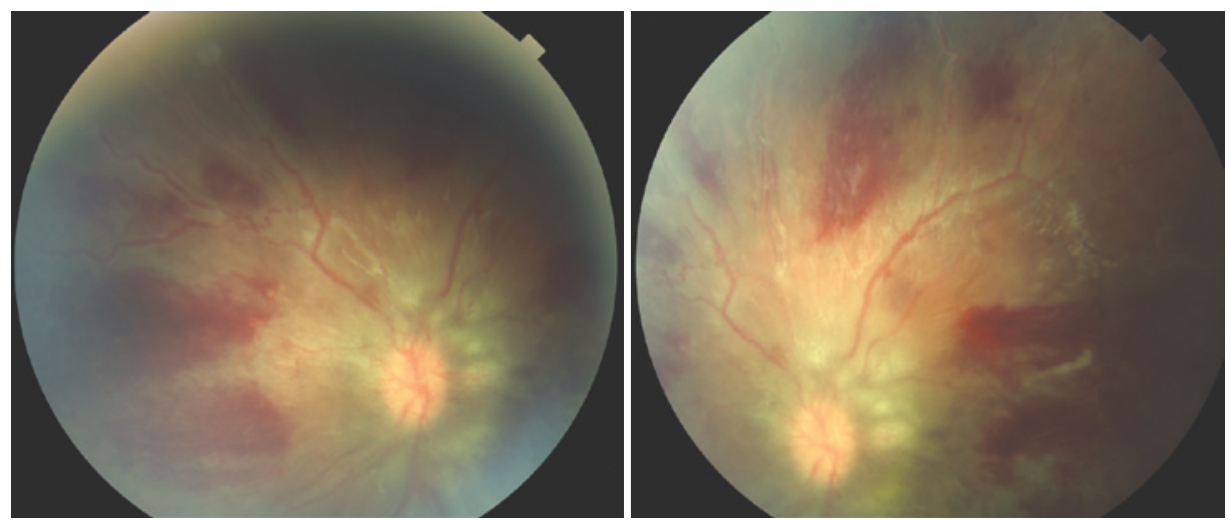

Figure 1. Fundus photograph demonstrating flame-shaped hemorrhages, neovascularization and optic disc swelling.
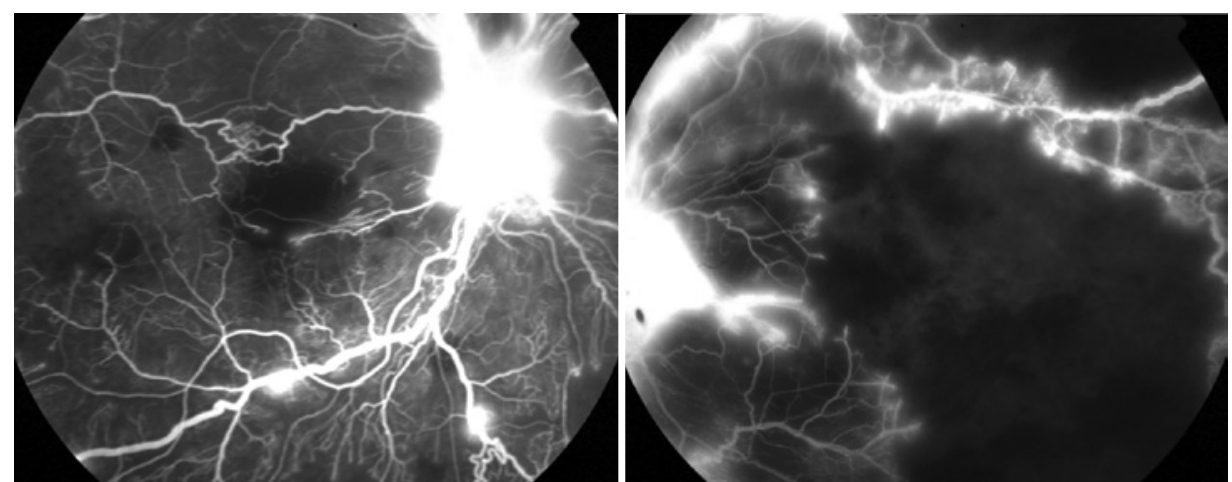

Figure 2. Fluorescein angiography demonstrating contrast leakage through the new vessels and nonperfused retinal areas. 

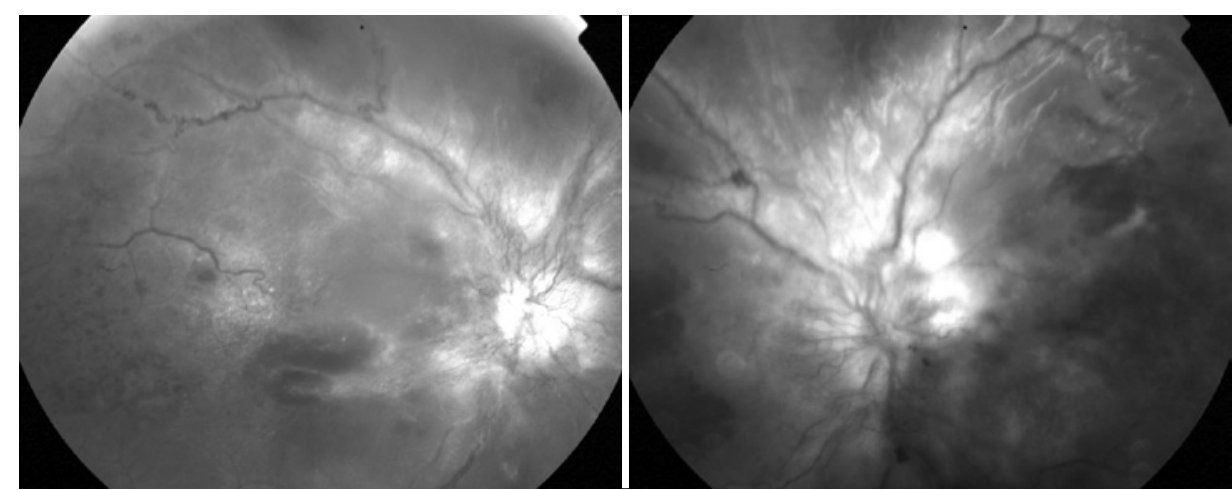

Figure 3. Fundus photograph.
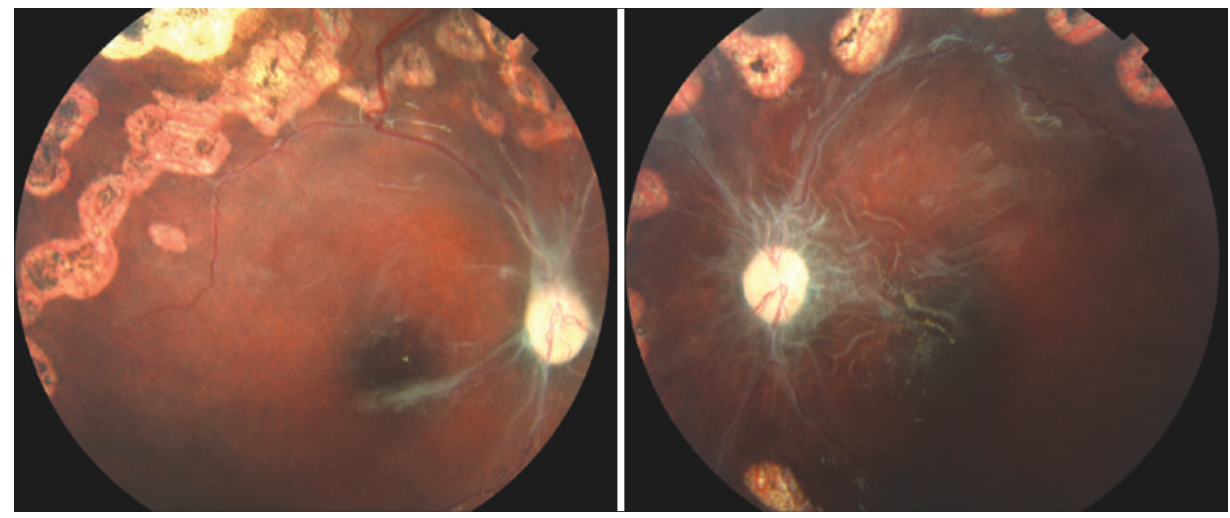

Figure 4. Fundus photograph after treatment with laser photocoagulation demonstrating regression of neovascularization

microcclusion, cotton wool spots, retinal hemorrhages, ischemia, and macular edema. Furthermore, no important worsening was observed in vascular tortuosity or venous dilatation, which further corroborates the diagnosis of Purtscher-like retinopathy.

The discussion of the case by the medical team focused on proposed treatments for the infant, the rarity of the case, and the severity and possible sequelae of retinal occlusive disease. The case was also discussed with members of the pediatric and nephrology departments of UFG. It was decided that the patient be treated by PRP with BIO in both eyes (Figure 2) to avoid a possible neovascular glaucoma, vitreous hemorrhage or tractional retinal detachment due to severe retinal ischemia. Six months after the laser treatment, the patient had visual sequelae, but with visual acuity better than at the initial evaluation. VA increased from 20/1000 OD and 20/540 OS to 20/540 in OD and 20/270 in OS. Fundus examination showed optic disc pallor and foveal pigmentary changes in both eyes. Optic and macular atrophy might have been the main factors for visual impairment.

HUS is a rare and potentially fatal disease and is unusual in its association with ocular findings. This case describes a Purtscher-like retinopathy in an infant with HUS, demonstrating the importance of ophthalmic evaluation, early diagnosis and treatment in patients affected by the disease.

\section{REFERENCES}

1. Gasser C, Gautier E, Steck A, Siebenmann RE, Oeshslin R. [Hemolytic-uremic syndrome: bilateral necrosis of the renal cortex in acute acquired hemolytic anemia]. Schweiz Med Wochenschr. 1955;85(38-39):905-9. German.

2. Siegler RL, Pavia AT, Christofferson RD, Milligan MK. A 20-year population-based study of postdiarrheal hemolytic uremic syndrome in Utah. Pediatrics. 1994;94(1):35-40.

3. Elkins SL, Wilson PP Jr, Files JC, Morrison FS. Thrombotic thrombocytopenic purpura: Evolution across 15 years. J Clin Apher. 1996;11(4):173-5.

4. Fitzpatrick MM, Dillon MJ. Current views on aetiology and management of haemolytic uraemic syndrome. Postgrad Med J. 1991;67(790):707-9.

5. Neuhaus TJ, Calonder S, Leumann EP. Heterogeneity of atypical haemolytic uraemic syndromes. Arch Dis Child. 1997;76(6):518-21.

6. Amirlak I, Amirlak B. Haemolytic uraemic syndrome: An overview. Nephrology (Carlton). 2006;11(3):213-8

7. Sturm V, Menke MN, Landau K, Laube GF, Neuhaus TJ. Ocular involvement in paediatric haemolytic uraemic syndrome. Acta Ophthalmol. 2010;88(7):804-7.

8. Medeiros HA, Medeiros JE, Caliari LC, Silva JF. Retinopatia de Putscher's and Putscher-like [revisão]. Rev Bras Oftalmol. 2009;68(2):114-9.

9. Siegler R, Oakes R. Hemolytic uremic syndrome: pathogenesis, treatment, and outcome. Curr Opin Pediatr. 2005;17(2):200-4.

10. Levin M, Barratt JM. Haemolytic uraemic syndrome. Arch Dis Child. 1984;59(5):397-400. 